\title{
A place migrants would call home: open- ended constructions and social determinants over time among Ecuadorians in three European cities
}

\author{
Paolo Boccagni $i^{1 *}$, Bernardo Armanni ${ }^{1}$ and Cristiano Santinello ${ }^{2}$
}

\author{
*Correspondence: paolo.boccagni@ \\ unitn.it \\ 'University of Trento - ERC \\ HOMInG, Trento, Italy \\ Full list of author information is \\ available at the end of the article
}

\begin{abstract}
Is there a place in particular that international migrants would call home? How do they talk about it, where does it lie, and what characteristics is it expected to have, given their demographics and patterns of settlement? Similar questions are meaningful in themselves and in illuminating migrant biographical, family and housing trajectories. We address them, in this paper, through the categorization and multinomial analysis of the responses to a dedicated open-ended question in a survey on Ecuadorians in Madrid, Milan and London $(n=1175)$. This original dataset allows us to explore migrant views of home against the background of their demographics and of their migration and housing conditions. We analyse respondents' ways to articulate, spatialize and prioritize key aspects of home through a logit model, thereby assessing their association with age, length of stay, housing tenure, family networks and city of residence. Overall, their predominant construction of home points to a place in the country of settlement, but not necessarily to their own dwelling. Younger and newcomer immigrants see home as a primarily relational construct, whereas older and long-stayers emphasize its place-based and private dimension. Significant variations in the expected emplacement and bases of home can be found across cities of residence. However, no significant variations are associated either with gender or with migrants' transnational engagement.
\end{abstract}

Keywords: Home, Place, Ecuadorian migration, Categorization, Length of residence, Age, City of residence

\section{Introduction}

Calling a place home is generally perceived as an ordinary, unreflexive way to relate to one's day-to-day environment. It acknowledges it, or selected parts of it, as more "special" and "personal" than the rest. Calling a place home, however, is neither a right or an opportunity given to all, or once for all, particularly for those who are not native to a place. International migrants are an oft-discussed case in point. At the early stage of their migration careers, and possibly even beyond, it is by no means self-evident what place, if any, they would call home. Particularly if that place lies in the country of

(c) The Author(s). 2021 Open Access This article is licensed under a Creative Commons Attribution 4.0 International License, which permits use, sharing, adaptation, distribution and reproduction in any medium or format, as long as you give appropriate credit to the original author(s) and the source, provide a link to the Creative Commons licence, and indicate if changes were made. The images or other third party material in this article are included in the article's Creative Commons licence, unless indicated otherwise in a credit line to the material. If material is not included in the article's Creative Commons licence and your intended use is not permitted by statutory regulation or exceeds the permitted use, you will need to obtain permission directly from the copyright holder. To view a copy of this licence, visit http://creativecommons.org/licenses/by/4.0/. 
settlement, their claims for home may not go uncontested (Boccagni, 2017; Duyvendak, 2011). However, their own constructions of home and their potential social determinants have hardly ever been investigated on a large and comparative scale. This paper contributes to address the omission, by exploring the prevalent constructions of a place to call home, and the temporal, relational and contextual factors associated with them, among Ecuadorian migrants in Europe. It draws on an archive of 1175 open-ended responses to a specific question within a survey on the views, experiences and practices of home that was conducted in Madrid, London and Milan in 2019 in the remit of HOMInG, a larger comparative study of migrant homemaking.

Asking migrants about a place they would call home is not only instrumental to understand what home means for them, and how this relates to their living and dwelling circumstances. It is also a way to uncover the factors associated with different "localizations" of home, and their implications for highly-discussed questions of belonging, membership and integration. With this in mind, we first approach the literature on migrants' experience of home. This shows that calling a place home can be fruitfully investigated as a performative act, rather than as a cognitive exercise (answering the question "where is home") or an emotional one (reporting "where one feels at home"). As we illustrate, the question Is there a place you would call home? elicits a variety of meaningful and sometimes ambiguous responses. We categorize them by exploring, first, migrant ways of articulating home as a self-evident place, or one that requires some reflection (How do Ecuadorian migrants talk about home?); second, their ways to localize home in different locations and scales (How do Ecuadorian migrants spatialize home?); last, their ways to privilege relational or spatial aspects in their own definitions (How do Ecuadorian migrants prioritize between different "foundations" of home?). To pave the way for the subsequent step - "why" they call home a place or another - we conduct logistic regressions on the association between demographic or structural factors and alternative constructions of home. Statistically significant factors include city and length of residence, age, housing tenure and family ties, but not interestingly - gender, nor transnational engagement. We pay particular attention, through margins analysis, to time-related independent variables, in order to ascertain their association with different constructions of home and to situate our argument in the emerging debate on home and migration. We contribute to it, overall, by revealing not only what "a place called home" (Massey, 1992) is expected to be like, but also how it is socially produced - what structural and biographical variables inform the very process of calling a place home. This is an individual act that is socially shaped and stratified, both along spatial and temporal lines.

\section{International migration and the struggle for a place to call home}

Home is a theoretically challenging concept. Its emic use in everyday life is as meaningful and evocative, as elusive and slippery. Scholars from different disciplinary backgrounds have conceptualized home as a way to capture a particular attachment and appropriation towards place on any scale, including one's domicile (Altman \& Werner, 1985; Cuba \& Hummon, 1993b; Kusenbach \& Paulsen, 2013; Moore, 2000).

As, potentially, any place (Gieryn, 2000), home indicates both a geographically located portion of space, and a set of relations and imaginaries that mark and (re)produce it over time (Blunt \& Dowling, 2006; Chapman, 2001; Massey, 1992). However, while 
any place can be seen as inherently relational and co-constructed (Cresswell, 2014; Gielis, 2009), there is something unique to home in terms of a "personal" and "regular investment of meaning" (Terkenli, 1995, p. 325). Home is typically understood as "a particularly significant kind of place with which, and within which, we experience strong social, psychological and emotive attachments" (Easthope, 2004, pp. 135-136). The debate on home across social sciences has increasingly acknowledged its processual texture, as an emplaced, implicitly exclusionary social relationship based on distinctive practices (Duyvendak, 2011; Boccagni \& Kusenbach, 2020). At the same time, the dependency of home on potentially mobile routines and relationships should not lead us to dismiss its spatial bases. As Douglas famously remarked, "space there must be", for "home starts from bringing some place under control" (Douglas, 1991, p. 289). And indeed, the view that a spatial subtext is critical to whatever is to be called home has informed our own research questions.

Nevertheless, researching home may end up in analysing the assemblage of relationships, emotions and memories associated with a place more than its spatial features as such. What is arguably most worth researching is how people locate and approach that special place - how they define it, what sense they make of it, what emotions they struggle to emplace onto it. There is a phenomenological side to home which is meaningful in itself, all the more so whenever there is no a priori reason to assume that the place one calls home should coincide with one's dwelling. This calls for a connection with the literature on place attachment (Lewicka, 2011a; Manzo \& Devine-Wright, 2020), place meanings (Manzo, 2005), and sense of place (Nelson et al., 2020). A recurrent argument across this literature is that people's "identification with place" is not necessarily tied to their will to stay there (Rönnlund, 2020); and that the development of a sense of place, including the one to be called home, involves an entanglement of social, cognitive and emotional elements, in addition to spatial ones (Nelson et al., 2020).

Admittedly, researching people's constructions of home is bound to be a partial effort. It unveils their self-representations but not necessarily their social practices. Whether the latter match with the former, and whether and how people do make themselves at home in their everyday lives is a question that can be fully addressed only through ethnographic fieldwork. That said, people's emic understandings of home are meaningful in themselves, in light of the social factors associated with them. Unlike social practices, such constructions can be fruitfully approached via large-scale surveys. We did so, in our study, by inviting people to talk about a place or condition they would call home. We can then expect the location (if any) and the expected qualities of that place to mirror their views and experiences of home, given their sociodemographics and living circumstances.

In investigating the subjective construction of home among people on the move, it is relatively common to ask where home is (e.g. Lucas \& Purkayastha, 2007). Such a straightforward question can be easily employed in a questionnaire format. Upon critical reflection, however, this is a problematic phrasing - and has therefore been excluded from our study. It takes for granted that a place called home does exist, which is not necessarily the case, as we show below. Moreover, it implicitly assumes that home means the same thing to all respondents.

An alternative phrasing would shift from a self-evident spatial register to an emotional one. People, including migrants (Feng \& Breitung, 2018), may be asked if and 
how they feel at home in certain places. This reflects a normative understanding of home as a "positive" condition (Blunt \& Dowling, 2006), and can capture a whole range of meaningful emotions. The fact remains, though, that feeling-at-home as an emotion is as significant and revealing as it is contingent and impermanent (Duyvendak, 2011; Miranda-Nieto et al., 2020).

Yet another approach, which informs our research, involves asking if there is a place people would spontaneously call home, to then explore its characteristics, against certain background variables. This is not meant to ask for a definition of home, which would be too much of an effort for a short-term and transient interview setting. Nor does it aim to a geographical or emotional understanding of home as a pre-existing place that people should merely identify, or connect themselves with. Calling a place home is more of a public, hence political question. Besides leaving more space for respondents' autonomous construction, it suggests a potential claim for place - the expectation that one's calling be recognized as legitimate, and that the place in question does operate as home, whether at a functional level or at an affective one. "Calling a place home", Klein et al. (2019, p. 7) maintain, "is an act of possession as well as one of marking and making meaning." It is "a statement of power" which articulates "a sense of entitlement, control and familiarity" toward a particular place (Shneer \& Aviv, 2010, p. 263). The frame of calling a place home is not exempt from normative subtexts, just like all the others. However, it is meant to encourage respondents to look at home as they perceive it in their actual life experience, rather than in wishful thinking.

Admittedly, a single question in a survey does not always elicit the deep reflexivity inherent in these statements. It is also tied to the particular historical and biographical moment in which the data is collected - just like all research based on one-time observation. Nonetheless, such a question does open up to place constructions that reach beyond the bricks and mortar of one's domicile, and are more faceted and socially embedded than those about home as emotion.

As our survey unfolded, by asking a selected sample of migrants what place they would call home we gathered a wide and diverse array of responses. We categorize them and explore their internal variations in light of respondents' housing and family conditions over time (measured by age and length of stay) and place (city of residence). Within the limitations of an exploratory and cross-sectional data collection, we investigate how people's construction of home is affected not only by extended mobility and differential patterns of settlement, but also, and perhaps more fundamentally, by different temporalities.

\section{Data and methodology}

Quantitative methodologies have been marginal, so far, in research on migrants' lived experience of home (among exceptions: Cuba \& Hummon, 1993a, 1993b; Lam \& Yeoh, 2004; Feng \& Breitung, 2018; Boccagni \& Vargas-Silva, 2021). This is no surprise for such a complex topic. Nonetheless, the variable locations and contents they connect with home can also be captured in a survey, with the attendant benefits for the reach and comparability of research findings. Following this premise, we investigate the constructions of home emerging from a survey on Ecuadorian migrants in Europe. Between July and December 2019, three local teams of interviewers collected 1175 questionnaires with first-generation Ecuadorians living in London (271 [23.1\%]), 
Madrid (518 [44.1\%]) and Milan (386 [32.8\%]). Respondents were recruited through sampling by centre (Blangiardo, 2008; Reichel \& Morales, 2017), with a focus on the local areas of their stronger concentration and visibility in the public space (e.g. "ethnic" restaurants and shops, parks, churches, consulates, etc.). The latter had been previously selected through exploratory fieldwork, including a pre-test of the questionnaire. Indeed, the preliminary findings of HOMInG (e.g. Miranda-Nieto \& Boccagni, 2020) contributed to shape and sharpen the survey guidelines. The questionnaires were administered face-to-face in Spanish, either by native speakers or by interviewers fluent in that language, all of them previously trained and subject to daily supervision during data collection. Interviewers were specially instructed to report as literally as possible the responses to the question at the core of this paper.

The choice of Ecuadorian migrants was justified by the potential of a comparative analysis of the same immigrant collective - one relatively well-settled by now (Ledesma, 2019) - across different national locations. As the bulk of migration from the Andean country to Europe took place soon after the 1999 crisis (Ramirez \& Ramirez, 2005), Ecuadorians in the selected cities make for a good target to investigate the stratified impact of temporality - i.e. of age and length of residence - on the construction of home. The option for a city level of analysis started from the recognition of cities themselves as, or more, than broader nation-states - as a key reference for home-related views and emotions, particularly among immigrants (Blunt \& Sheringham, 2019). Our city selection aimed to enable a comparison between different local infrastructures (Castaneda, 2018), with variable "language proximity", for immigrant integration. For sure, the relative weight of Ecuadorians differs substantially between the three cities. London has the smallest number $(15,000)$ relative to overall population size and is the most distant to Ecuador, language wise (Mcllwaine et al., 2011). Madrid hosts a large Ecuadorian community (90,000, including dual citizens) and has the closest cultural connection to Ecuador, given its colonial history (Iglesias et al., 2015). Milan has an Ecuadorian population $(14,000)$ that is smaller than in London in absolute terms, and yet much higher, relative to overall population size (Pilati, 2012). Its language proximity falls between Madrid and London. ${ }^{1}$

As the previous literature shows, these cities correspond to significantly different structures of opportunity along indicators such as access to residence and work permits, prospects for citizenship acquisition, family reunion rights, access to social welfare and political participation (Cinalli et al., 2014; Morales \& Pilati, 2014). The ensuing patterns of difference point to the promise of a cross-city comparative approach. As important for the purpose of our analysis, Ecuadorian respondents in London have an average length of residence ( 9 years) that is far lower than either Madrid or Milan (15 years) - a difference that is consistent with the data already available (Ledesma, 2019). About $60 \%$ of our London participants are secondary migrants from another European country.

We base our analysis on a logistic or multinomial logistic regression model (logit), which we chose because we assume that errors follow the standard logistic distribution

\footnotetext{
${ }^{1}$ Data on Ecuadorians in the UK comes from Vargas-Silva's analysis of the 2017 UK Labour Force Survey (mimeo); data on Ecuadorians in Spain comes from the Padrón Municipal of the Municipality of Madrid (2020); data on Milan has been specially estimated by ISMU (2020) - a think-tank specialized in surveys on immigrant populations.
} 
and for the sample size better described by this type of model. Rather than validating hypotheses given in advance, we follow an exploratory approach, as needed for an open-ended question that had never been addressed on a large scale before. In practice, we advance different theory-driven categorizations of the responses. We then measure the socio-structural factors that co-variate with the modalities of each variable; that is, the alternative ways to articulate, spatialize and characterize a "place to call home".

We start from the independent variables that significantly co-vary with our dependent ones, and develop regression models to ascertain three key results: the statistical significance of a relation between dependent and independent variables; the magnitude of each independent variable's effect in terms of probability; the predicted probability of falling into each dependent variables' category, given the values of independent variables. Before including independent variables in the models, we made sure that no multicollinearity ${ }^{2}$ existed between them. To do this, we estimated and evaluated the values of variance inflation factor (VIF), tolerance and those in the correlation matrix of independent variables. ${ }^{3}$

In principle, as the literature shows, migrant views of home may be affected by a whole range of variables (Boccagni, 2017; Cuba \& Hummon, 1993a; Feng \& Breitung, 2018): age and gender, education, length and place of residence, housing conditions, legal status and family ties, but also - in a transnational optic - the frequency of return visits and home ownership in the country of origin (Table 1).

As our preliminary analysis showed, however, some of these variables have no significant influence on the likelihood that respondents construct home in a way or another. Consistent with this, we exclude from our final model citizenship status, frequency of return visits and home ownership in Ecuador and gender, after checking their lack of explanatory power in all the subsequent models.

Both models we employ are based on logistic regression, or logit analysis. The correspondent equation to estimate the model is based on a logarithmic function, in which the weighted sum of factors is made into a probability value:

$$
Y=\ln \left(\frac{p}{1-p}\right)=\ln \left(\frac{P(Y=1)}{P(Y=0)}\right)=\beta_{0}+\beta_{1} X_{1}+\beta_{2} X_{2}+\beta_{k} X_{k}+\epsilon
$$

In this function, working as the core of multivariate analysis, $\beta^{k}$ represents the number of independent variables and $X^{\mathrm{k}}$ (regression coefficient) represents the way in which each $X_{\mathrm{k}}$ (Predictor) predicts values of the dependent variable Y. Last, $p$ is defined as the probability of $Y=1$ as opposed to $Y=0$.

Our models estimate the parameters of each independent variable in terms of odds ratios (OR) which measure the probability of an association between each predictor condition and the resulting outcome. We estimate the probability of a case falling into one of the 2 (or 3) modalities of the dependent variables given a certain condition, against that of the same result in absence of such a condition. The outcome's

\footnotetext{
${ }^{2}$ The co-existence, in the model, of factors having overlapping effects.

${ }^{3}$ Our concern was to exclude the existence of this effect especially between age and length of residence. The mean value found of the VIF index is 1.20 , whereas the correlation between the two variables, the highest among all the combinations of the independent variables, is only 0.35 .
} 
Table 1 Frequency distribution of independent variables

Total

\section{Gender}

Female

Male

Age class

\begin{tabular}{ll} 
Until 30 years & 27.1 \\
$30-45$ years & 35.7 \\
$46-60$ years & 31.8 \\
Over 60 years & 5.4 \\
\hline (Mean) & 40.6
\end{tabular}

Age (Mean)

Length of residence

0-5

6-10

11-15

$15+$

Length of residence (Mean)

City

London

Madrid

Milan

Education

Primary or less

Secondary

Tertiary or over

Housing tenure

Owner

Tenant

Subtenant or informal dweller

Dual citizenship

No

Yes

Family distribution

No close family members

Only in Ecuador

Only in country of interview

Both in Ecuador and country of interview

\section{Frequency of return visits}

At least once a year

Less than once a year

Never or almost never

Real estate in Ecuador

Owned a house before

Built it or has been building it

No - Not interested

No - But would like to 
Table 1 Frequency distribution of independent variables (Continued)

\begin{tabular}{ll}
\hline & Total \\
\hline $\mathrm{N}$ & 1175 \\
\hline
\end{tabular}

probability is calculated given a category of an independent variable (e.g. house tenants) vis-à-vis its reference category (e.g. house owners).

\section{On categorizing "a place you would call home"}

At the core of our analysis lies one open-ended question: Is there one place in particular you would call "home?”. In Spanish: ¿Hay algun lugar en particular que Ud. llamaría "casa", en el sentido de "hogar"? This phrasing came after pretesting the questionnaire and after in-depth discussions with Spanish native speaker colleagues. Hogar is the closest translation of home in Spanish. However, since it has some semantic overlapping with household, we opted to connect it with the lived environment of casa, sentirse en casa being the exact translation of feeling at home.

Upon survey administration, the question encountered very high response rates (98.7\%). As important, and by no means obvious, over $90 \%$ of respondents do mention a place they would call home. Such a place does not necessarily overlap with their dwelling place, the country where they live, or the place in which they would like to live in the everyday. Moreover, some respondents reinterpreted the question to include relational, emotional or spiritual conditions that are hardly reducible to one place as "a unique spot in the universe" (Gieryn, 2000, p. 464).

Responses range from two-letter words to lengthy and elaborate reflections. Grouping them into distinct categories was not without costs, as no analytical reduction could fully capture the diversity of a qualitative archive of views of home. The categorization evolved incrementally, in order to deal with conceptual residuals and analytically ambiguous responses ${ }^{4}$ (Lupia, 2018; Niedomysl \& Malmberg, 2009). Even so, all final categories have a share of residuals or missing cases. ${ }^{5}$

Three research questions oriented the categorization, aiming to a stepwise exploration of the ways in which migrants talk about home (how), of the places they associate it with (where), of the expected qualities of a place they would call home (what):

1. How do Ecuadorian migrants represent home to themselves and convey it to others? Is it a self-evident notion, or one that requires some reflection on their side?

2. How do Ecuadorian migrants spatialize home? Is their construction of home anchored to one place in particular? If so, does it overlap with their dwellings, or anyway with the country in which they live?

\footnotetext{
${ }^{4}$ At an initial stage, all authors individually read the entire set of responses. This enabled them to set the boundaries of a limited number of categories, based both on theoretical concerns and on the preliminary reading of the responses. At a later stage, one single coder (i.e. Armanni) coded all the relevant responses, in order to prevent biases in inter-coder reliability (Lamprianou, 2020). On all uncertain cases, i.e. about 15\%, a decision was taken through extended consultation between all authors.

${ }^{5}$ These range between $0.4 \%$ and $11,5 \%$ of the dataset, mostly overlapping with "No" responses. The incidence rises to $28 \%$ for "Emplacing home at country level", since many responses are not reducible to either the immigration or the emigration country.
} 
3. Content wise, what are the qualities migrants prioritize in calling a place home? Is it a matter of relationships (i.e. people associated with it), of dwelling (i.e. the right or possibility to stay there), or of attachment to some public space?

We first give a descriptive response to these questions, prior to exploring one underlying question, why, by estimating the effect of the models' explanatory factors. Last, we focus on another fundamental question, when (i.e. how the lived experience of time is connected with the construction of home), through conditional marginal estimation by age and length of stay. Whenever relevant, we use brief and selected excerpts from the responses themselves, as a way to exemplify the underlying argument.

As a preliminary step, we set apart the negative responses - those that articulate the absence of a place to call home (8\%). ${ }^{6}$ These suggest a remarkable over-exposure to social disadvantage. The respondents are significantly over-represented among those in substandard housing conditions. Relative to house owners, tenants are 2.5 times more likely to say that they have no place to call home, with subtenants and informal dwellers being 7 times more likely to do so $(\mathrm{OR}=7.55)$. An even stronger effect is associated with living in Madrid $(\mathrm{OR}=13.3)$ and to a lesser extent in Milan $(\mathrm{OR}=4.2)$, relative to London. The presence of family members, instead, makes less likely the perceived absence of a place to call home. This holds if relatives are located only in the country of interview (6.6 times less likely), but also, to a lesser extent, both "here" and "there" (5.3 times) or only in the country of origin (2.7 times). Family networks, therefore, are as important as housing conditions in mitigating the risk that immigrants feel having no place whatsoever to call home. Holding dual citizenship exerts also some influence. Dual citizens are twice more likely to give a positive response than Ecuadorian-only citizens $(\mathrm{OR}=0.48)$.

\section{Calling a place home: three analytical understandings and the underlying factors}

By reading through the open-ended responses in the survey in light of our research questions we built a number of heuristic categories. We take them as dependent variables to capture the facets and determinants of the process of calling a place home. While each category is autonomous from the others, their cumulative analysis enables us to "enter" into the social construction of home, starting from the ways in which migrants talk about it, moving to the relevant space(s), to finally explore the expected qualities of home as a place (Table 2).

\section{How do Ecuadorian migrants talk about home?}

"The ongoing relevance of home", writes Stock (2010, p. 27), "lies in the fact that it is not only an analytical tool, but an emic term which is highly salient for diasporic subjects themselves. While for them the ambivalence of home is a lived reality, the term continues to suggest self-evidence". Following this insight, we first interrogate migrant ways of articulating home: whether and why calling home a certain place is indeed a straightforward, almost natural act, or one that requires some reflection - as if migrants

\footnotetext{
${ }^{6} \mathrm{We}$ include these responses under the category Articulating home, which focuses on how the response was given, while excluding them from the subsequent ones, which presuppose the existence of some place to be called home.
} 
Table 2 Logistic regression models for the dependent variables by age, length of residence, city, housing tenure and family distribution

\begin{tabular}{|c|c|c|c|c|c|c|c|c|c|c|c|}
\hline & & \multirow{2}{*}{\multicolumn{2}{|c|}{$\begin{array}{l}\text { Articulating } \\
\text { home } \\
\text { Self-evident } \\
(71 \%) \\
\text { vs } \\
\text { Reflexive } \\
(29 \%)\end{array}$}} & \multirow{2}{*}{\multicolumn{2}{|c|}{$\begin{array}{l}\text { (Un)Matching } \\
\text { Dwelling and } \\
\text { home } \\
\text { Dwelling- } \\
\text { based (41\%) } \\
\text { vs } \\
\text { Non- } \\
\text { Dwelling- } \\
\text { based (59\%) }\end{array}$}} & \multirow{2}{*}{\multicolumn{2}{|c|}{$\begin{array}{l}\text { Emplacing } \\
\text { home at } \\
\text { country level } \\
\text { Origin }(27 \%) \\
\text { vs } \\
\text { Settlement } \\
(73 \%)\end{array}$}} & \multicolumn{4}{|c|}{$\begin{array}{l}\text { Laying down } \\
\text { the foundations of home } \\
\text { People (37\%) } \\
\text { vs }\end{array}$} \\
\hline & & & & & & & & \multicolumn{2}{|c|}{$\begin{array}{l}\text { Private } \\
\text { places } \\
(36 \%)\end{array}$} & \multicolumn{2}{|c|}{$\begin{array}{l}\text { Public } \\
\text { places } \\
(27 \%)\end{array}$} \\
\hline & & \multicolumn{2}{|c|}{$N=1170$} & \multicolumn{2}{|c|}{$N=1.072$} & \multicolumn{2}{|c|}{$N=845$} & \multicolumn{4}{|c|}{$N=1042$} \\
\hline & & OR & $\sigma(\mathrm{OR})$ & OR & $\sigma(\mathrm{OR})$ & OR & $\sigma(\mathrm{OR})$ & OR & $\sigma(\mathrm{OR})$ & OR & $\sigma(\mathrm{OR})$ \\
\hline Age & & 0.99 & 0.275 & 0.98 & $0.034^{* *}$ & 0.98 & $0.014^{* *}$ & 1.02 & $0.030^{* *}$ & 1.00 & 0.493 \\
\hline \multirow{3}{*}{$\begin{array}{l}\text { Length of } \\
\text { residence (ref. } \\
0-5 \text { ) }\end{array}$} & $6-10$ & 0.93 & 0.746 & 0.71 & 0.237 & 2.02 & $0.015^{* *}$ & 1.59 & 0.158 & 0.86 & 0.572 \\
\hline & $11-15$ & 0.60 & $0.070^{*}$ & 0.35 & $0.000^{* * *}$ & 4.53 & $0.000^{* * *}$ & 3.68 & $0.000^{* * *}$ & 1.10 & 0.771 \\
\hline & $15+$ & 0.75 & 0.191 & 0.43 & $0.001^{* * *}$ & 5.92 & $0.000^{* * *}$ & 2.85 & $0.001^{* * *}$ & 1.48 & 0.132 \\
\hline \multirow{2}{*}{$\begin{array}{l}\text { City (ref. } \\
\text { London) }\end{array}$} & Madrid & 0.39 & $0.000^{* * *}$ & 0.14 & $0.000^{* * *}$ & 2.64 & $0.000^{* * *}$ & 4.82 & $0.000^{* * *}$ & 0.49 & $0.001^{* * *}$ \\
\hline & Milan & 1.65 & $0.009^{* * *}$ & 0.47 & $0.001^{* * *}$ & 0.68 & 0.123 & 0.90 & 0.719 & 0.21 & $0.000^{* * *}$ \\
\hline \multirow{2}{*}{$\begin{array}{l}\text { Housing } \\
\text { Tenure (ref. } \\
\text { Owners) }\end{array}$} & Tenants & 1.46 & $0.080^{*}$ & 1.30 & 0.173 & 0.45 & $0.007^{* * *}$ & 0.64 & $0.048^{* *}$ & 0.95 & 0.861 \\
\hline & Subtenants & 1.41 & 0.193 & 2.35 & $0.002^{* * *}$ & 0.21 & $0.000^{* * *}$ & 0.50 & $0.028^{* *}$ & 0.78 & 0.460 \\
\hline \multirow{3}{*}{$\begin{array}{l}\text { Family } \\
\text { Distribution } \\
\text { (ref. No one) }\end{array}$} & $\begin{array}{l}\text { Ecuador } \\
\text { only }\end{array}$ & 1.98 & 0.203 & 0.72 & 0.619 & 2.34 & 0.190 & 0.73 & 0.721 & 0.20 & $0.019^{* *}$ \\
\hline & $\begin{array}{l}\text { Interview } \\
\text { only }\end{array}$ & 2.45 & $0.100^{*}$ & 0.31 & $0.068^{*}$ & 7.48 & $0.003^{* * *}$ & 0.98 & 0.983 & 0.14 & $0.005^{* * *}$ \\
\hline & Both & 1.74 & 0.294 & 0.43 & 0.177 & 3.44 & $0.051^{*}$ & 0.96 & 0.967 & 0.18 & $0.009^{* * *}$ \\
\hline \multicolumn{2}{|l|}{ Pseudo $\mathrm{R}^{2}$} & \multicolumn{2}{|l|}{0.08} & \multicolumn{2}{|l|}{0.17} & \multicolumn{2}{|c|}{0.19} & \multicolumn{2}{|l|}{0.13} & & \\
\hline
\end{tabular}

were to explain it in light of their life conditions. In fact, the self-evidence of home tends to resist even under conditions of structural ambivalence (Boccagni \& Kivisto, 2019). The responses that depict home as self-evident, with a few words like "My place", "In Ecuador", or "My family", outnumber (70.9\%) those based on a more extended and reflexive argumentation. The latter include, for instance, "After living in different countries in my life, it's difficult for me to distinguish one place as home"; or, "My home is my family, so my home is where they are. I miss my family in Ecuador very much but where my sons and my husband are is now my home". Similar responses suggest that, consistent with Stock's (2010) argument, home as a concept is "far from self-evident", and yet it keeps "carrying strong connotations of exactly such self-evidence" (Stock, 2010, p. 25). There is a remarkable continuity, in this respect, between data collected on different migrant populations, at different times, in different national contexts.

Home, among the Ecuadorian migrants we interviewed, is mostly an unquestioned cognitive asset that is readily available for discursive use. Reflexive responses, instead, emphasize (73\%) the relational aspects of place, i.e. people living there. Their weight is halved (14\%) among those who have no place to call home. Such a condition seems clear and stark enough to need no further explanation. Having said this, which factors are associated with these opposite ways to articulate home?

Part of the answer has to do with the city of residence (Table 2). Ecuadorians in Milan are 1.6 times more likely to give a reflexive response than in London. By contrast, those in Madrid are 2.6 times less likely to do so. Calling a place home is more of an immediate and spontaneous act in this city, where Ecuadorians are part of a larger 
"colony" of co-nationals and are fully able to make themselves at home language wise. Moreover, tenants are more likely to give reflexive responses than homeowners. In short, the weight of reflexive responses can hardly be ascribed to mere individual attitudes. External conditions affect even the responses to such an intimate question. Under unfavourable circumstances, talking about home goes with the need to justify why a certain place or condition should be called home at all. Furthermore, immigrants with family members in the country of interview are 2.5 times more likely to give a reflexive response than those with no family members. This points to the centrality of family in the definition of home, as we elaborate below. Last, long-residents are somewhat more likely to "naturalize" home. However, this is a minor effect (significant only in the 11-15 yrs. class), which is why we omit the "articulating" category from the subsequent margins analyses.

\section{How do Ecuadorian migrants spatialize home?}

Telling if there is a place to call home, and what it looks like, illuminates also the spatial construction(s) of home. To what locations(s) and scale(s), if any, do migrants connect home? What factors account for the variations in its emplacement?

Transnational migration is sometimes associated with a de-spatialization of home, as if people on the move were in a position to make themselves at home wherever, or "in mobility" as such (Germann-Molz, 2008; Rapport \& Dawson, 1998). In fact, the literature on place attachment tends to dismiss these claims (DiMasso et al., 2019; Gielis, 2009; Lewicka, 2011b). So does our data on first generation, relatively well-settled labour migrants. Their views of home are predominantly anchored to specific territorially-bounded contexts (e.g. "Where my children were born, Santa Rosa, El Oro"; "My childhood house, where I grew up with my parents"; "The house I've purchased"; "The Ecuadorian bar close to home"). That said, about $20 \%$ of responses focus exclusively on aspects detached from any specific anchoring in space, such as kinship and affective ties ("With my child, wherever"), emotional states ("Rest, peace and comfort") or ideal conditions ("Where I can have a future to thrive"). The city of residence is the only factor that significantly affects the internal distribution of this variable. The city with the highest rate of "anchored" responses is Madrid, followed by London and Milan.

While a large majority of Ecuadorian migrants anchor home to a particular location, this is not necessarily their present dwelling (Nowicka, 2007), contrary to a very ordinary assumption in home studies (e.g. Terkenli, 1995). Almost $60 \%$ of respondents call home a place that lies elsewhere. This embraces a variety of reference points, testifying to the complexity of the notion of home beyond the house (Blunt \& Dowling, 2006; Windsong, 2010): family as such ("I couldn't say a physical place - home for me is where my family is"); language ("I feel home wherever, if I know the language and can communicate"); locations connected to migrant past lives ("My place of origin in Ecuador - I was born there, and there I would like to die"); the built or natural environment ("A typical restaurant;" "The countryside and the mountains"); or emotional states, as highlighted above.

City of residence is the factor that most accounts for respondents' ways to (mis)match home and dwelling (Table 2). Ecuadorians in Madrid are 7.1 times more likely 


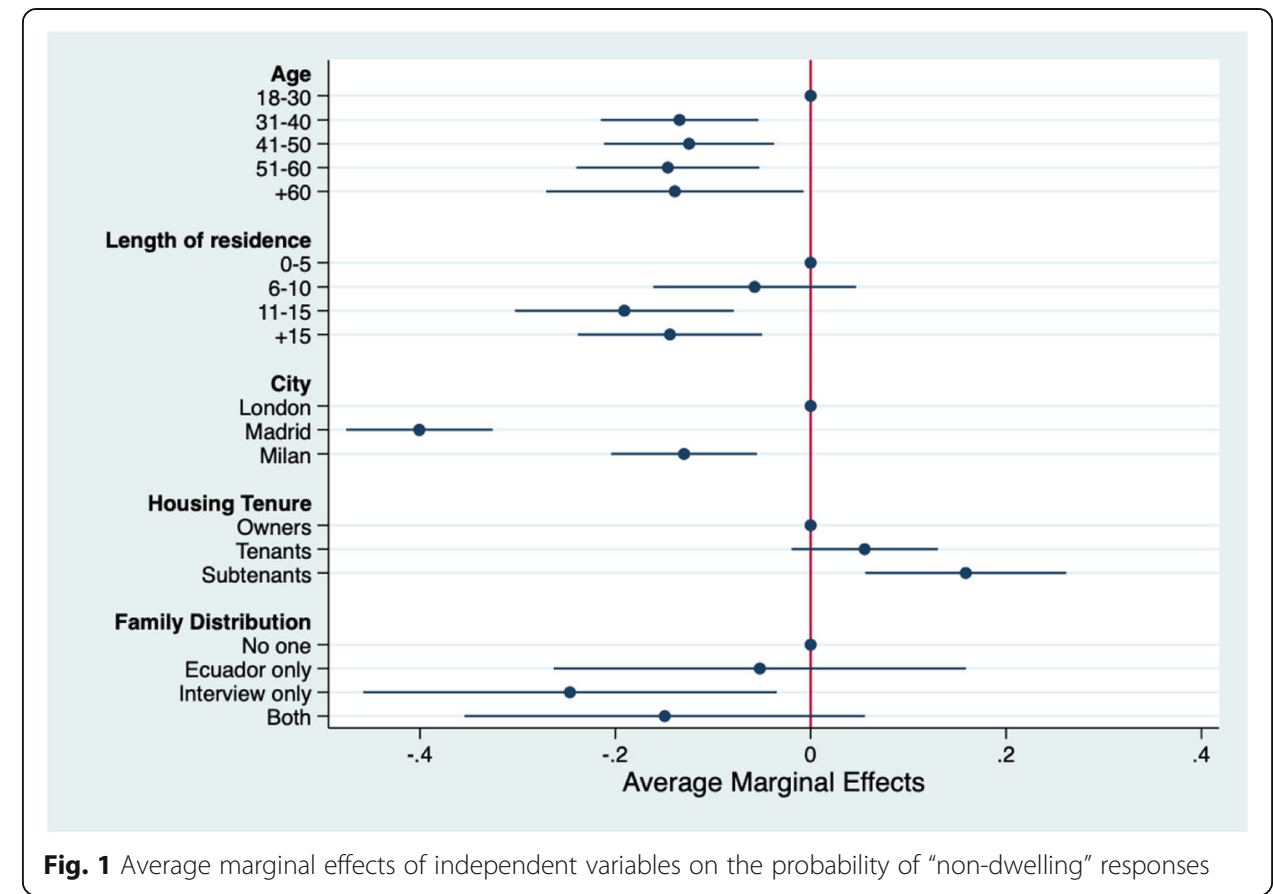

than in London to call their dwelling home, and those in Milan twice more likely than in London. Furthermore, migrants with relatives only in the country of interview are 3.2 times more likely to do so, compared with those with no family members. The orientation to call home one's dwelling increases with length of residence (by 2.9 times from newcomers to the 11-15 yrs. range, and by 2.3 times from the former to longresidents) and with age (1.02 times for each increased year) (cf. Cuba \& Hummon, 1993a). Last, and perhaps unsurprisingly (Bate, 2018), subtenants are 2.4 times less likely than homeowners to call their dwellings home.

Figure 1 shows the average marginal effects ${ }^{7}$ of the modalities of each independent variable in the model on the probability of "non-dwelling" responses (and then of the subsequent categories - see Figs. 2 and 3). This enables us to estimate the net effects of each variable on the overall probability of the outcomes. Effects in probability are represented in the $x$-axis, while the modalities of each independent variable are represented in the $y$-axis. The ' 0 ' point on the $x$-axis indicates no effect of a given modality with respect to the reference one.

Importantly, a conspicuous majority (73\%) calls home a place that lies in their country of settlement rather than in the one of origin. The distinction may be oversimplistic, as it applies only to three responses out of four. ${ }^{8}$ It does not necessarily mean that migrants are more likely to call home the "hostland" than the "homeland" at an intimate and essential(istic) level, the opposite may be true (Boccagni, 2017). It

\footnotetext{
${ }^{7}$ A marginal effect (ME), or partial effect, measures the effect on the conditional mean of $y$ of a change in one of the regressors, i.e. $x_{j}$.

${ }^{8}$ The category excludes a share of responses (cf. footnote 5) having no specific national location (e.g. "The place of my uncles"), or referring to different countries (e.g. "Bilbao, Spain" stated by one interviewee in London) or to both of them (e.g. "Ecuador and Spain"). Out of the scope of this category are also the responses that cannot be pinned down to one particular place (e.g. "Where I can see a future", or "Where my family is").
} 


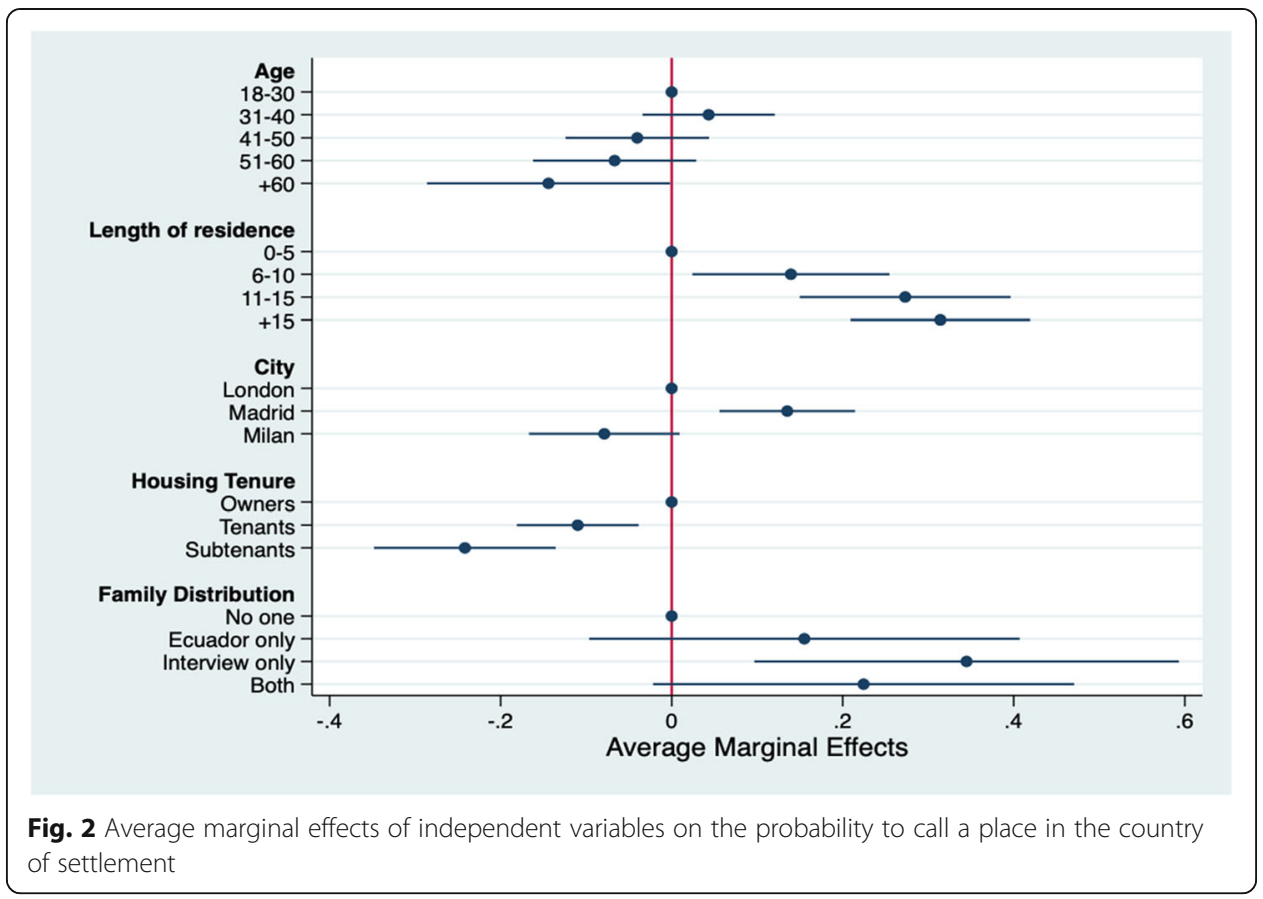

does mean, more pragmatically, that the place they call home lies somewhere on the immigrant side of their life experience, far more often than on the emigrant one. This may be the dwelling, but also, in one case out of three, other settings including workplaces or other people's dwellings ("My sister's place"); neighbourhoods, cities or entire countries ("Aravaca/Pozuelo"; "London is my home"; "Spain, I consider it my homeland and home by now"); public spaces that elicit memories of the past ("The Consulate when I come here I feel a bit like in Ecuador, I see many people from my country here"; "Living in Madrid makes me very happy, parks and open spaces here are beautiful, they make me feel like at home"). The construction of home out of the dwelling but in the hostland is articulated only by ca. 200 respondents, which invites caution in data analysis. That said, typical respondents are younger and with a higher length of residence than the others. It is reasonable to infer that they are predominantly young immigrants who came after family reunification and are emotionally attached to the country in which they live, but not to the dwelling conditions accessible to them.

Importantly, the emplacement of home at country level is not associated with indicators of cross-border engagement such as transnational homeownership or return visits. Those migrants who invested in transnational housing, or visit Ecuador on a yearly basis, are no more likely than the others to call their country of origin home. Instead, the ways to emplace home at a country level are primarily associated with the spatial distribution of close family members (Fig. 2). Assuming "no family members" as reference category, the presence of family only in the country of interview makes for 7.5 times higher likelihood to emplace home there. Having kin on both "sides" results in a 3.4 times difference. Time-related factors are also important and, interestingly, at odds with each other. Age, estimated linearly in the model, has a negative effect. For each extra year of age, respondents are 1.02 times less likely to call home a place in the country of settlement. Instead, length of residence has a strong positive effect. Relative 


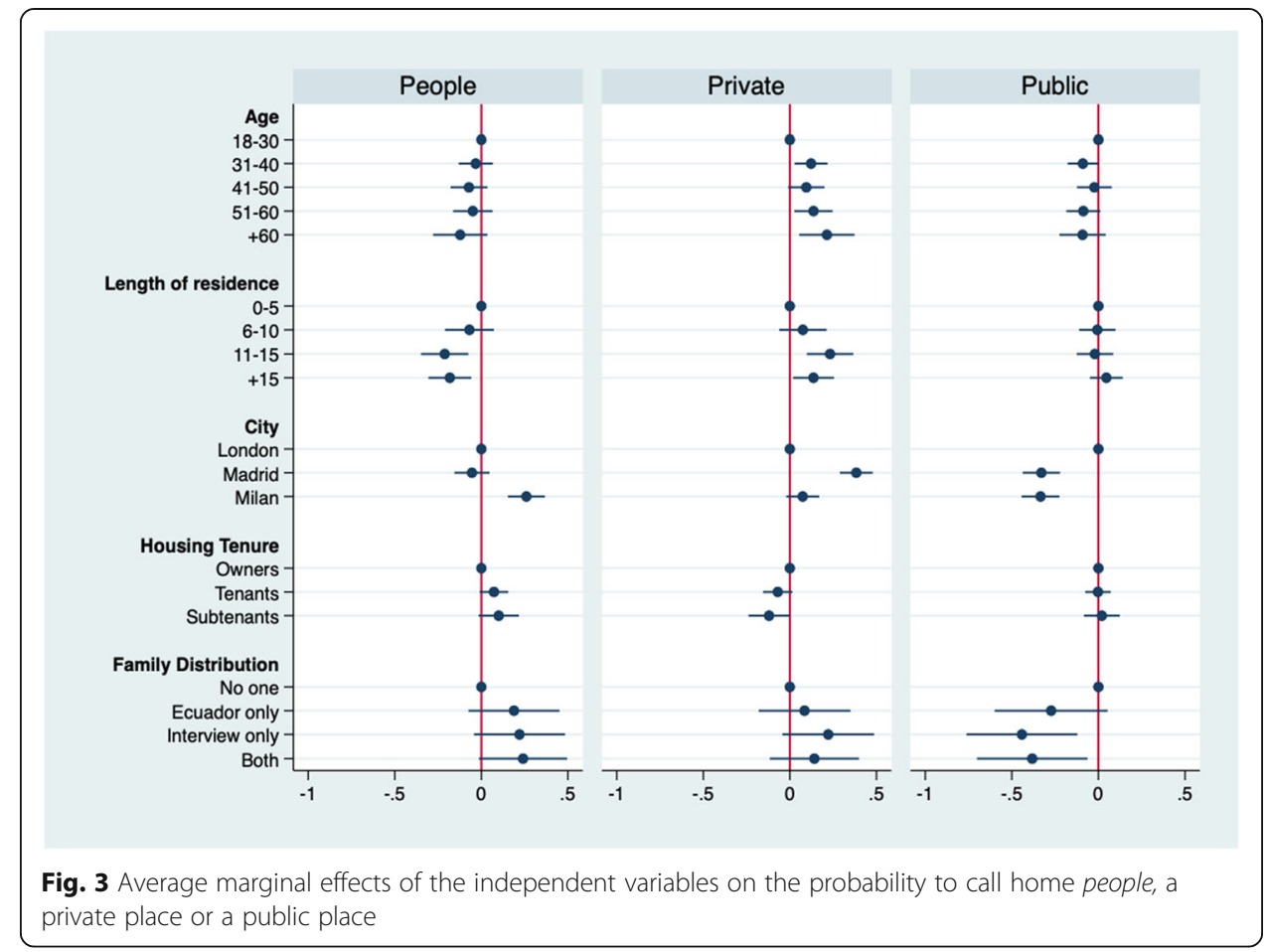

to newcomers, migrant longer-residents have from two to six times higher likelihood to emplace home there. We will return to the contrasting effects of these measures of temporality in the next section. Furthermore, Ecuadorians in Madrid are 2.6 times more likely to see home in the country of settlement, relative to those in London. Spain as a country is more amenable to be called home than, respectively, the UK or Italy. This feeds into the critical significance of a (common and native) language for people to make themselves at home (Altman \& Werner, 1985). Last, the emplacement of home in the country of settlement is more likely among migrants with higher housing stability.

\section{How do Ecuadorian migrants prioritize between different "foundations" of home?}

We have so far assessed whether home as a place is self-evident or not, and on what scale(s) it is spatialized. However, what expected characteristics qualify it and make it unique? Is home primarily defined by the presence of certain people? Or instead, is the "homeliness" of a place based on the very possibility to live in it, or on certain spatial characteristics? For sure, a certain relationality is inherent in any definition of place. As Massey famously put it (Massey, 1992, p. 12), "a 'place' is formed out of the particular set of social relations which interact at a particular location" (cf. also Gielis, 2009). Nevertheless, it is important to trace how, and possibly why migrants privilege relational or more generally spatial and infrastructural aspects in their own constructions of home.

In this perspective, we first distinguish the relational responses (37.2\%). These associate home with family members or friends, with embedded memories ("The house of my grandpa, where I spent wonderful moments with all my family... he died before I left for 
Italy"), or with other relational aspects ("Spain, because I've got involved in social activism here"). However, many more responses point exclusively to the locality and materiality of the place called home. Following an extended tradition in social theory (Brighenti, 2010), we can distinguish private spaces like dwellings ("A nice and tidy house, with all I need to live"; "Where I can do whatever I like - a place I must have bought, it must be mine"; "Both my house in Quito and my house here"), and public spaces on all scales ("Sitting in the park, breathing the air"; "The gym"; "Ecuador because it's where I was born plus if I compare where I lived elsewhere, there's nothing alike"; "Spain, it's where I grew up and where I want to stay"). Following this categorization, are migrants' constructions of home based primarily on people, on private spaces (their dwellings or other houses), or on public spaces (as a catchword for spatial references that do not fall in the former categories)?

The ensuing dependent variable is tripartite, with People and Private having a similar weight, and Public a lesser one. The multinomial logistic regression model calculates the probabilities of single cases falling into Private and Public, with People as reference category (Table 2). The distribution of the responses across cities of residence shows remarkably distinctive patterns. Each city has a different modality as its statistical mode. Relative to London, participants in Madrid are 4.8 times more likely to construct home in terms of Private places rather than People. Moreover, respondents in both Milan and Madrid are more likely to connect their constructions of home to People as opposed to Public places. Those in Madrid are twice more likely to do so than in London, those in Milan 4.8 more likely than the latter.

The net effects of housing tenure, length of residence and age are significant in the comparison between the People and Private categories. Homeowners are 1.6 times more likely than tenants, and twice more likely than subtenants, to opt for a Privaterather than a People- based construction of home. On the other hand, long-residents are 2.9 to 3.7 times more likely to answer Private instead of People, relative to newcomers. Consistent with the literature (Cuba \& Hummon, 1993a), older migrants articulate constructions of home based on habituation to the place in which they live, more than on relations with people. For each one-year increase in age, the model estimates an increased likelihood of 1.02 .

Finally, respondents with relatives only in the country of interview are seven times more likely to call home a place connected with people, compared to those without family members. Interviewees with relatives in both countries or only in Ecuador are about five times more likely to have the same outcome. Interestingly, the distribution of family members makes no significant difference to the distribution of Private and People. This could be due to the fact that respondents with close family members in the country of interview may be living with them. For those cases, Place and People tend to overlap with each other because of an implicit "household" dimension. The location of family members is instead significant when comparing Private and Public responses. Interviewees in closer proximity to their relatives are more likely to construct home on Private rather than Public bases, particularly if relatives live only in the country of residence. Spatial and temporal factors also play a role. Interviewees from Madrid and Milan are respectively 9.9 and 4.4 times more likely to give a Private rather than a Public response, relative to those in London. Such probability is positively affected by length of residence. 
In sum, the construction of home as a private place, regardless of those living in it, is more likely in Madrid and among older people, long-residents, those living closer to family members and those with more stable housing tenure. Relational constructions of home, compared to "private" ones, are negatively affected by the same factors.

\section{Predicting the constructions of home over time: a discussion through marginal analysis}

We can now reconnect with the literature on migrants' experience of home over time (Cuba \& Hummon, 1993b; Miranda-Nieto et al., 2020) by assessing, in terms of predictive margins, ${ }^{9}$ the respective influence of age and length of residence on the three variables on which more robust findings have emerged: the (un)matching of dwelling and home, the emplacement of home at a country level and the prioritization of alternative bases of home.

While most respondents (59\%) call home a place other than their dwelling, their likelihood to do so decreases over time, in terms both of age and length of residence (Fig. 4). Across the age spectrum, newcomers are systematically more likely to disconnect home from dwelling, relative to those settled for over 10 years. And regardless of length of stay, people in their twenties have a $12 \%$ higher probability to mismatch home and dwelling, compared with their 60 yrs. old counterparts. Put differently, older migrants are more likely to construct their domicile as home (Walsh \& Nare, 2016). Overall, younger newcomers are $80 \%$ likely not to call home their dwellings, whereas less than half of older long-residents would do the same. Length of residence and age, therefore, play a similar role in predicting the (un)matching of dwelling and home. As the migration and biographical times go by, migrants are increasingly likely to call home their dwelling places.

The probability to locate home in one's country of settlement, instead, is affected negatively by age and positively by the length of residence (Fig. 5). However, the length of residence effect is far stronger than the age one. At every age of respondents, longresidents are almost 30\% more likely to call home a place in their country of settlement than newcomers, although the difference decreases over 11 years of residence. Age, in turn, accounts for $14 \%$ of the probability - elder migrants are $14 \%$ less likely than younger ones to emplace home in their country of settlement. Altogether, migrants tend to increasingly emplace home in their countries of settlement over time.

Given the lack of statistical interaction between the two time variables, we can exclude that older migrants, including long-residents, would be more likely to emplace home in the country of origin because they have lived there longer. Instead, the effect of age is homogeneous across lengths of stay, indicating a net effect, to be further inquired. Elderly people, regardless of their migratory experience, may be expected to emphasize more nostalgic memories of their youth and childhood, relative to their younger counterparts (Lundgren, 2010). The process of calling a place home could be no exception in this regard (Meijering \& Lager, 2014). Alternatively, the effect of age may have to do less with ageing than with a cohort or generational effect which, again, calls for more research. Older generations might be expected to value more homeland

${ }^{9}$ With adjusted predictions we compute the probability of the event occurring for an individual, overall or for each modality of a single independent variable. 


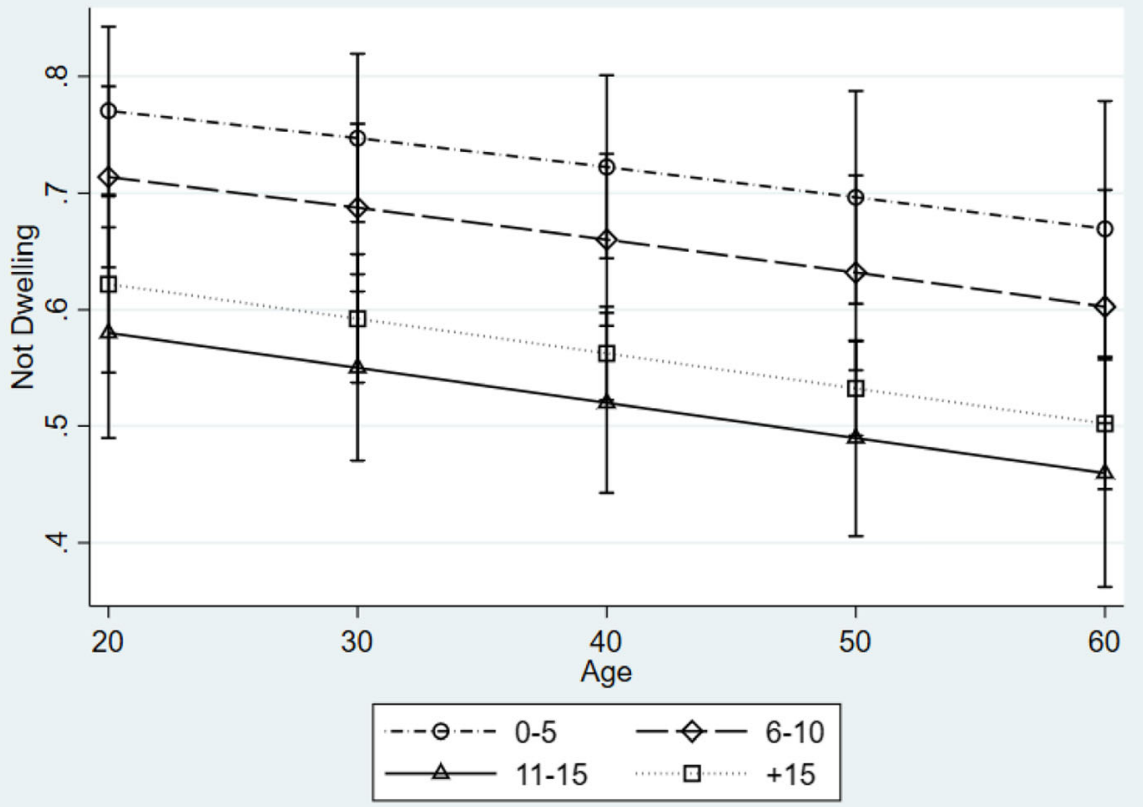

Fig. 4 Predictive margins of Unmatching dwelling and home by age and length of residence

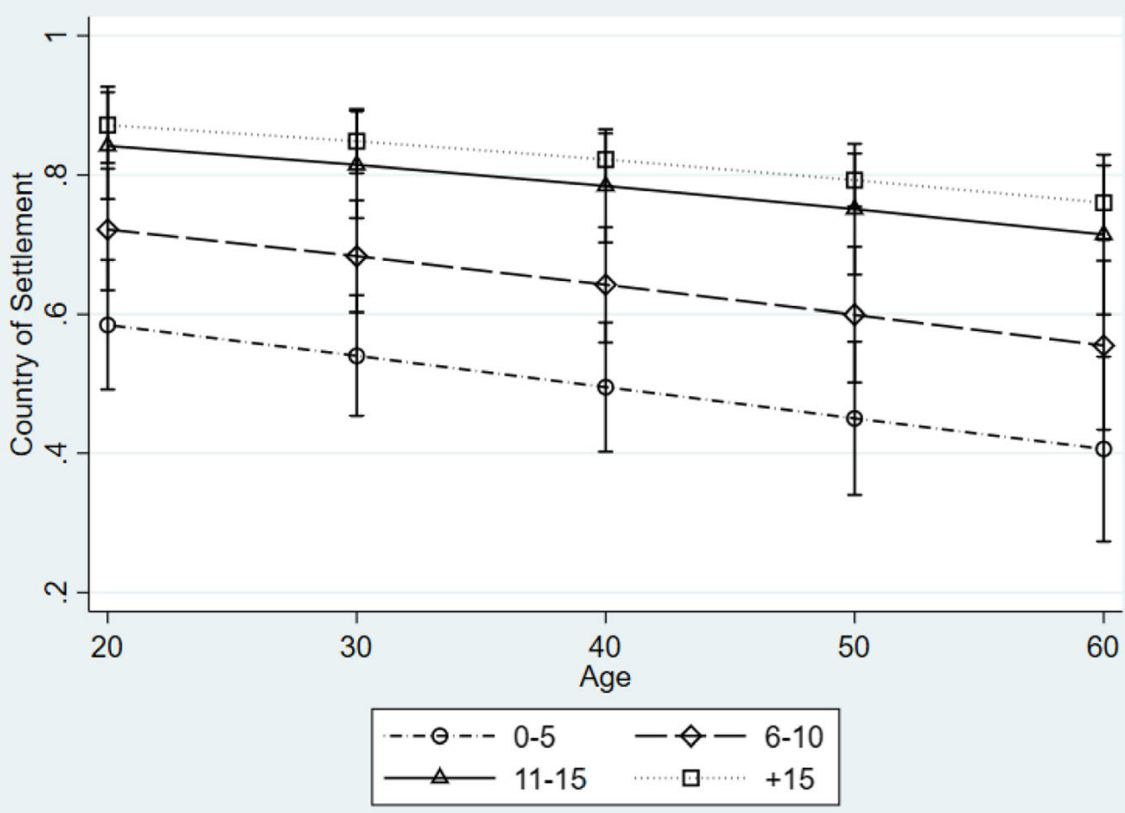

Fig. 5 Predictive margins of Emplacing home in country of settlement by age and length of residence 
belonging and 'roots' (hence to be more attached to Ecuador). Younger generations might instead be more 'cosmopolitan' (cf. Beck \& Beck-Gernsheim, 2009), thereby evaluating their country of birth as relatively less important than their current situation.

Last, the constructions of home as primarily a matter of People or Private places follow opposite trends, whereas the probability of calling a Public place home tends to remain the same across ages (Fig. 6). Relational constructions of home are most prevalent among younger respondents, with a probability over $40 \%$, dropping around $30 \%$ for older ones. By contrast, the probability to call home a Private place rises from $30 \%$ in the younger cohort to over $40 \%$ in the older one. Migrants in their forties are almost as likely to construct home as a "peopled" and "private" place. These findings corroborate Cuba and Hummon's (1993a) emphasis on the life course, since the construction of home relies primarily on one's own dwelling among older immigrants, while depending more on relationships with family and friends among younger ones.

The probability of opting for People or Private places across ages varies significantly with length of residence too (Fig. 7). While the effect of age does not vary with migrants' lengths of stay, the model provides very different probability values across them. For young newcomers (up to 40 yrs. old, up to 5 yrs. abroad), the probability of constructing home as a matter of People (55\%) is thrice higher than as a Private place, and twice higher than a Public one. Among newcomers in their 60s, the likelihood to answer People falls (45\%), but remains the most probable outcome (although in a less statistically significant way). Put differently, immigrant newcomers are significantly more likely to connect home to a place with particular people. However, their likelihood to do so decreases, as their age increases.

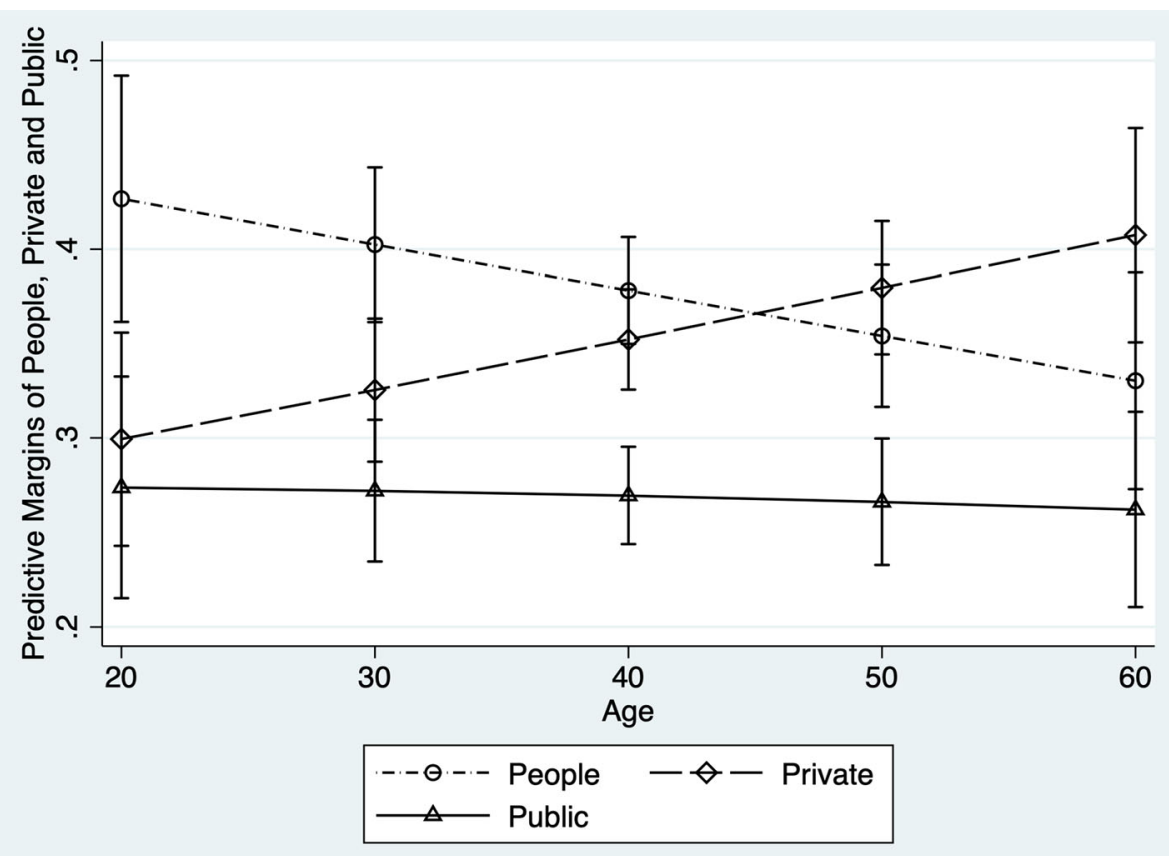

Fig. 6 Predictive margins of Laying down the foundations of home by age 


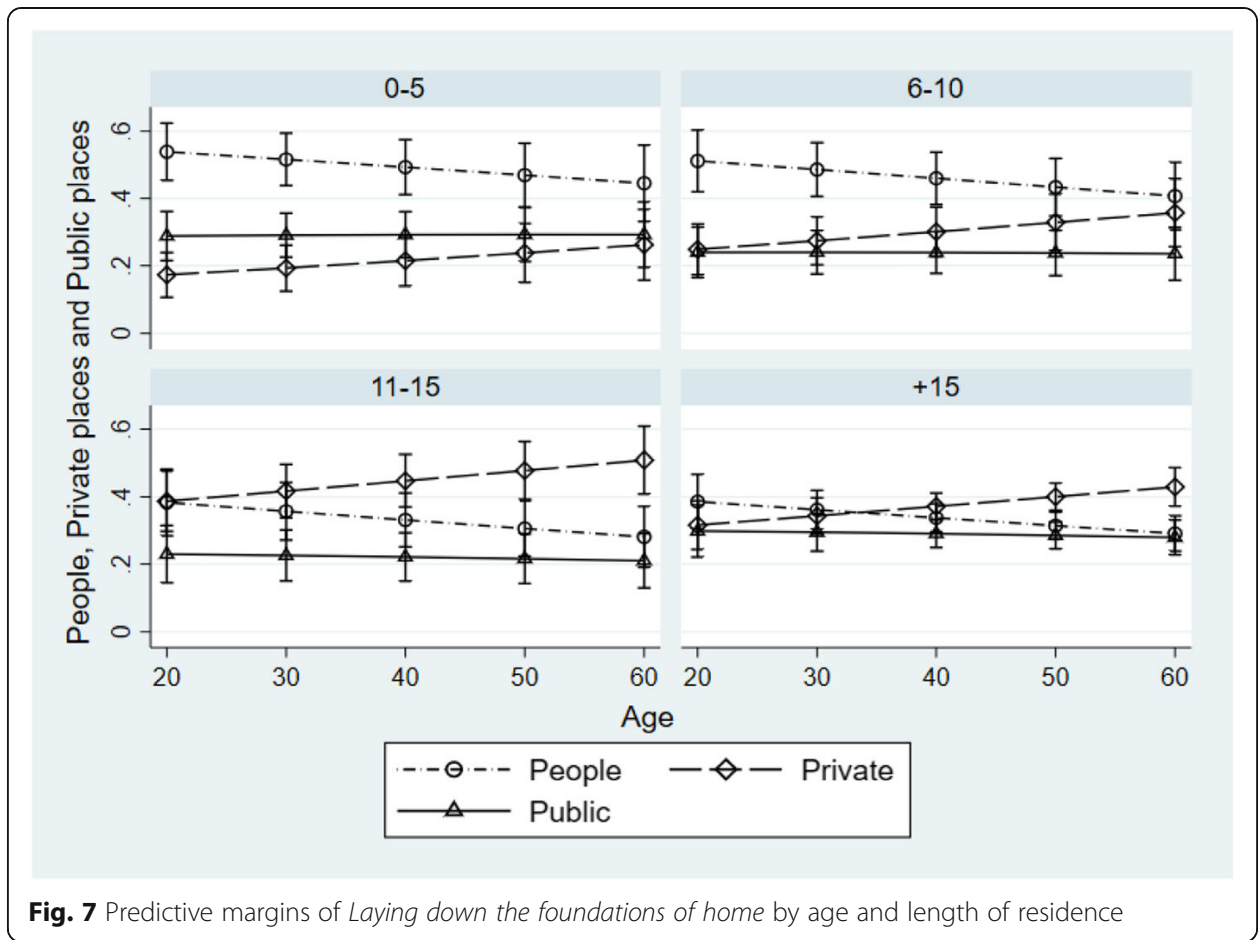

As a matter of fact, changes in the age spectrum account for a stronger identification with home as a private place as such ( $21 \%$ increase in its probability), rather than one that is primarily qualified by those who inhabit it ( $12 \%$ decrease in its probability). Statistically speaking, however, age affects significantly only the probability to call home a private space. Length of residence is more important, as overall it heightens the probability of a Private response by $23 \%$, decreasing that of relational constructions of home by $21 \%$, with a solid statistical significance.

Regardless of age, immigrant newcomers call a place home in light of the people living there, more than out of an attachment to a particular place. After about a decade spent abroad, the private dimension of home emerges as the predominant one. Approaching migrant preferred foundations of home by age and length of stay, therefore, reveals a fundamental transition from relations-based to house-based understandings of home along immigrants' life course and along their process of settlement. In both cases, the relevance of social relations in the construction of home decreases over time in a linear way. The opposite occurs with the probability to call private spaces home. The construction of home as a public place, instead, retains a secondary weight irrespective of time factors.

\section{Conclusion}

The large majority of the Ecuadorian migrants we interviewed in Madrid, Milan and London do point to a specific and distinctive place they would call home. This generally corresponds to a particular location, rather than to an abstract condition, an emotion or a phantasy about it. It tends to be situated in their country of settlement, all the more so if they have family members there and after at least a decade spent there (which is mostly the case, among Ecuadorians in Europe). While their age exerts a 
counter-pressure, as older migrants have more of a pull toward the country of origin, this is a comparatively minor one. However, the place they would call home is often not the one in which they dwell - their own house. The opposite is more likely to occur in Madrid, among homeowners who live with their close family members. Surprisingly, no significant association was found with variables measuring respondents' transnational connections such as homeownership in Ecuador and frequency of return visits. As remarkable, gender has no influence on the ways in which migrants articulate, spatialize or prioritize home - male and female migrants follow precisely the same patterns of response. These vary significantly across cities and, time wise, are shaped primarily by their length of stay. For sure, home tends to mean different things at different points in the life course. It is more of a relational condition for younger people, and of a place-based one among the elderly. Overall, though, it is "the years they have" as immigrants what most enables us to predict where they would locate their own home.

Calling a place home in a particular timespace is an exercise that articulates one's shifting priorities in evoking the dear ones, the materiality of a place which offers everyday protection, the possibility to exert control on it, and one's own roots in Ecuador. Prioritizing one of these aspects over the others, or combining them in different ways, is an ongoing balancing act between memories of the past, perceived conditions in the present, aspirations and concerns for the future. At the same time, it is neither a merely improvised act or a random one. Rather, it follows distinctive patterns of association with specific factors, as our analysis shows. For sure, the possibility to call a place home is not given for all, or once for all. About $8 \%$ of respondents do not see any place they would call home, given their present life conditions. Moreover, it does not necessarily match with living in a place that meets the normative standards and expectations evoked by the notion of home.

All this being said, a trend is clear in the prevalent location of home somewhere in the country of residence, over time, as a pragmatic condition that becomes normal and calls for neither reflection or justification. The most surprising finding out of our exploratory study is probably that men and women articulate the same structure of preference, discourse wise, regardless of the large differences and inequalities that likely exist in their opportunities to make themselves at home, including in domestic, care and reproductive work. This calls for further comparative research into the interplay between home-related views and underlying social practices, both within immigrant communities and across the divide between majority and minority populations.

Acknowledgements

The authors are grateful to their respondents, as well as to the interviewers, in Madrid, Milan and London.

Authors' contributions

The authors read and approved the final manuscript.

Funding

Research for this article has been funded by the European Research Council, Grant no. 678456 (HOMInG - the homemigration nexus). 


\section{Declaration}

\section{Competing interests}

The authors declare that they have no competing interests.

\section{Author details}

${ }^{1}$ University of Trento - ERC HOMInG, Trento, Italy. ${ }^{2}$ University of Trento, Trento, Italy.

Received: 15 December 2020 Accepted: 9 August 2021

Published online: 15 October 2021

\section{References}

Altman, I., \& Werner, C. (1985). Home Environments. New York: Plenum. https://doi.org/10.1007/978-1-4899-2266-3.

Bate, B. (2018). Understanding the influence tenure has on meanings of home and homemaking practices. Geography Compass, 12(1), e12354. https://doi.org/10.1111/gec3.12354.

Beck, U., \& Beck-Gernsheim, E. (2009). Global generations and the trap of methodological nationalism for a cosmopolitan turn in the sociology of youth and generation. European Sociological Review, 25(1), 25-36.

Blangiardo, G. (2008). The Centre sampling technique in surveys on foreign migrants (Eurostat Working paper 12). Eurostat. Blunt, A., \& Dowling, R. (2006). Home. London: Routledge. https://doi.org/10.4324/9780203401354

Blunt, A., \& Sheringham, O. (2019). Home-city geographies. Progress in Human Geography, 43(5), 815-834. https://doi.org/10.11 $77 / 0309132518786590$

Boccagni, P. (2017). Migration and the search for home. London: Palgrave.

Boccagni, P., \& Kivisto, P. (2019). Ambivalence and the social processes of immigrant inclusion. Intenational Journal of Comparative Sociology, 60(1-2), 1-10

Boccagni, P., \& Kusenbach, M. (2020). For a comparative sociology of home: Relationships, cultures, structures. Current Sociology, 68(5), 595-606.

Boccagni, P., \& Vargas-Silva, C. (2021). Feeling at home across time and place. Population, Space and Place, 27(6), 1-13. Brighenti, A. (2010). The publicness of public space (vol. 49). Trento: Quaderni DSRS.

Castaneda, E. (2018). A place to call home. Stanford: UP. https://doi.org/10.1515/9781503605770.

Chapman, T. (2001). There's no place like home. Theory Culture and Society, 18(6), 135-146. https://doi.org/10.1177/02632 760122052084

Cinalli, M., et al. (2014). LOCALMULTIDEM and MDE institutional political opportunity structures indicators (WP1; Version V2) [Data set]. Harvard Dataverse. https://doi.org/10.7910/DVN/27709.

Cresswell, T. (2014). Place. New York: Wiley.

Cuba, L., \& Hummon, D. (1993a). Constructing a sense of home. Sociological Forum, 8(4), 547-572. https://doi.org/10.1007/ BF01115211.

Cuba, L., \& Hummon, D. (1993b). A place to call home. Sociological Quarterly, 34(1), 111-131. https://doi.org/10.1111/j.15338525.1993.tb00133.x.

DiMasso, A., et al. (2019). Between fixities and flows. Journal of Environmental Psychology, 61, 125-133. https://doi.org/10.1016/ j.jenvp.2019.01.006.

Douglas, M. (1991). The idea of a home. Social Research, 58(1), 287-307.

Duyvendak, J. (2011). The politics of home and the United States. Springer. https://doi.org/10.1057/9780230305076.

Easthope, H. (2004). A place called home. Housing, Theory and Society, 21(3), 128-138. https://doi.org/10.1080/1403609041 0021360.

Feng, D., \& Breitung, W. (2018). What makes you feel at home? Population Space and Place, 24(3). https://doi.org/10.1002/ psp.2116.

Germann-Molz, J. (2008). Global abode. Space and Culture, 11(4), 325-342. https://doi.org/10.1177/1206331207308333.

Gielis, R. (2009). A global sense of migrant places. Global Networks, 9(2), 271-287. https://doi.org/10.1111/j.1471-0374.2009.002 54.x.

Gieryn, T. (2000). A space for place in sociology. Annual Review of Sociology, 26(463-96), 1. https://doi.org/10.1146/annurev. soc.26.1.463.

Iglesias, J., et al. (2015). La población de orígen ecuatoriano en España. Comillas: Embajada del Ecuador.

Klein, E., et al. (Eds.) (2019). Performing dream homes. London: Palgrave. https://doi.org/10.1007/978-3-030-01581-7.

Kusenbach, M., \& Paulsen, K. (Eds.) (2013). Home. Frankfurt: Lang. https://doi.org/10.3726/978-3-653-03560-5.

Lam, T., \& Yeoh, B. (2004). Negotiating 'home' and 'national identity'. Asia Pacific Viewpoint, 42(2), 141-164.

Lamprianou, I. (2020). Measuring and visualizing coders' reliability. Sociological Methods \& Research. https://doi.org/10.1177/ 0049124120926198

Ledesma, N. (2019). Ecuador migration trends. Inter-American Dialogue. Retrieved from https://www.thedialogue.org/wpcontent/uploads/2019/04/Ecuador-Migration-Trends.pdf.

Lewicka, M. (2011a). Place attachment. Journal of Environmental Psychology, 31(3), 207-230. https://doi.org/10.1016/j.jenvp.201 0.10 .001

Lewicka, M. (2011b). On the varieties of people's relationships with places. Environment and Behavior, 43(5), 676-709. https:// doi.org/10.1177/0013916510364917

Lucas, S., \& Purkayastha, B. (2007). "Where is home?" Here and there: transnational experiences of home among Canadian migrants in the United States. GeoJournal, 68, 243-251. https://doi.org/10.1007/s10708-007-9073-0.

Lundgren, A. S. (2010). In the good old days. Journal of Aging Studies, 24(4), 248-256. https://doi.org/10.1016/j.jaging.2010.05. 005.

Lupia, A. (2018). How to improve coding for open-ended survey data. In The Palgrave handbook of survey research (pp. 121 127).

Manzo, L. C. (2005). For better or worse: Exploring multiple dimensions of place meaning. Journal of Environmental Psychology, 25(1), 67-86. https://doi.org/10.1016/j.jenvp.2005.01.002. 
Manzo, L. C., \& Devine-Wright, P. (Eds.). (2020). Place attachment. London: Routledge. https://doi.org/10.4324/9780429274442. Massey, D. (1992). A place called home? New Formations, 17, 3-15.

Mcllwaine, C., Cock, J. C., and Linneker, B. (2011). No Longer Invisible: the Latin American Community in London. Trust for London: London.

Meijering, L., \& Lager, D. (2014). Home-making of older Antillean migrants in the Netherlands. Ageing \& Society, 34(5), 859875. https://doi.org/10.1017/S0144686X12001377.

Miranda-Nieto, A., \& Boccagni, P. (2020). At Home in the Restaurant: Familiarity, Belonging and Material Culture in Ecuadorian Restaurants in Madrid. Sociology, 54(5), 1022-1040.

Miranda-Nieto, et al. (2020). Ethnographies of home and mobility. London: Routledge.

Moore J. (2000). Placing home in context. Journal of Environmental Psychology, 20(3), 207-217. https://doi.org/10.1006/jevp.2 000.0178 .

Morales, L., \& Pilati, K. (2014). The political transnationalism of Ecuadorians in Barcelona, Madrid and Milan. Global Networks, 14(1), 80-102. https://doi.org/10.1111/glob.12018.

Nelson, J., et al. (2020). Sense of place. Journal of Urbanism, 13(2), 236-261.

Niedomysl, T., \& Malmberg, B. (2009). Do open-ended survey questions on migration motives create coder variability problems? Population, Space and Place, 15(1), 79-87. https://doi.org/10.1002/psp.493.

Nowicka, M. (2007). Mobile locations. Global Networks, 7(1), 69-86. https://doi.org/10.1111/j.1471-0374.2006.00157.x.

Pilati, K. (2012). Network resources and the political engagement of migrant organisations in Milan. Journal of Ethnic and Migration Studies, 38(4), 671-688. https://doi.org/10.1080/1369183X.2012.640491.

Ramirez, J., \& Ramirez, F. (2005). La estampida migratoria ecuatoriana. Quito: Abya-Yala.

Rapport, N., \& Dawson, A. (Eds.) (1998). Migrants of identity. Oxford: Berg.

Reichel, D., \& Morales, L. (2017). Surveying immigrants without sampling frames. Comparative Migration Studies, 5(1). https:// doi.org/10.1186/s40878-016-0044-9.

Rönnlund, M. (2020). I love this place, but I won't stay. Young, 28(2), 123-137. https://doi.org/10.1177/1103308818823818.

Shneer, D., \& Aviv, C. (2010). Jews as rooted cosmopolitans? In K. Knott, \& S. McLoughin (Eds.), Diasporas. London: ZED. https://doi.org/10.5040/9781350219595.ch-044

Stock, F. (2010). Home and memory. In K. Knott, \& S. McLoughin (Eds.), Diasporas. London: ZED.

Terkenli, T. (1995). Home as a region. Geographical Review, 85(3), 324-334. https://doi.org/10.2307/215276.

Walsh, K., \& Nare, L. (Eds.) (2016). Transnational migration and home in older age. London: Routledge. https://doi.org/10.4324/ 9781315713564

Windsong, E. A. (2010). There is no place like home. The Social Science Journal, 47(205-14), 1. https://doi.org/10.1016/j.soscij.2 009.06.009.

\section{Publisher's Note}

Springer Nature remains neutral with regard to jurisdictional claims in published maps and institutional affiliations.

\section{Submit your manuscript to a SpringerOpen ${ }^{\circ}$ journal and benefit from:}

- Convenient online submission

- Rigorous peer review

- Open access: articles freely available online

- High visibility within the field

- Retaining the copyright to your article

Submit your next manuscript at $\boldsymbol{\sim}$ springeropen.com 